\title{
Identifikasi Mutu Buah Pepaya California (Carica Papaya L.) Menggunakan Metode Jaringan Syaraf Tiruan
}

\author{
Muhammad Ezar Al Rivan ${ }^{[1]}$, Gabriela Repca Sung ${ }^{[2]}$ \\ Teknik Informatika ${ }^{[1],[2]}$ \\ STMIK Global Informatika MDP \\ Palembang, Indonesia \\ meedzhar@mdp.ac.id ${ }^{[1]}$,gabrielarepca12@gmail.com ${ }^{[2]}$
}

\begin{abstract}
Papaya is one of the fruits that grows in the tropics area, one of the kinds that people's love the most is papaya California. The quality identification of papaya California fruit can be measured using color, defect, and size. Color, defect and size extracted from image of papaya. The dataset that used in this research are 150 images papaya California. The dataset consist of 3 quality there are good, fair and low. Identification of papaya using the backpropagation neural network method with 17 training function in each training data with 3 different neurons in the hidden layer. The best result of the test is using training function trainrp with 10 neurons is $81,33 \%$ for accuracy, $73,37 \%$ for precision, and $72 \%$ for recall, with 20 neurons is $82,67 \%$ for accuracy, $75,24 \%$ for precision, and $74 \%$ for recall, and with 25 neurons is $\mathbf{8 0 , 8 9 \%}$ for accuracy, $\mathbf{7 4 , 4 2 \%}$ for precision, and $\mathbf{7 1 , 3 3 \%}$ for recall.
\end{abstract}

Keywords- Artificial Neural Network, Backpropagation, Identification quality, Papaya

Abstrak- Pepaya adalah buah yang tumbuh pada daerah tropis, salah satu jenis buah pepaya yang paling digemari oleh masyarakat adalah buah pepaya California. Identifikasi mutu buah pepaya California dapat diukur dengan menggunakan

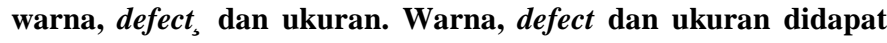
dengan melakukan ekstraksi dari citra pepaya. Dataset yang digunakan berjumlah 150 citra pepaya California. Dataset terdiri dari 3 ukuran kualitas pepaya yaitu, bagus, sedang dan jelek. Pengujian dilakuakn dengan menggunakan metode jaringan syaraf tiruan backpropagation dengan menggunakan 17 training function pada setiap data latih dengan 3 neuron berbeda untuk setiap hidden layernya. Berdasarkan pengujian yang telah dilakukan didapatkan hasil yang terbaik yaitu dengan menggunakan training function trainrp pada neuron 10 menghasilkan accuracy sebesar $81,33 \%$, precision sebesar $73,37 \%$, dan recall sebesar $72 \%$, sedangkan pada neuron 20 menghasilkan accuracy sebesar $82,67 \%$, precision sebesar $\mathbf{7 5 , 2 4 \%}$, dan recall sebesar $\mathbf{7 4 \%}$, kemudian untuk neuron 25 menghasilkan accuracy sebesar $\mathbf{8 0 , 8 9 \%}$, precision sebesar

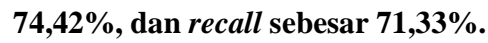

Kata Kunci- Jaringan syaraf tiruan, Backpropagation, Identifikasi mutu, Pepaya

\section{INTRODUCTION}

Tanaman Pepaya (Carica papaya L.) adalah tanaman yang dapat tumbuh pada daerah tropis dan aslinya berasal dari daerah Amerika Tengah dan tersebar luas di Pasifik Selatan serta daerah tropis lainnya. Wilayah tropis dengan curah hujan yang memadai dan mempunyai suhu berkisar antara $21-23^{\circ} \mathrm{C}$ merupakan tempat yang sangat cocok untuk tumbuh kembang papaya [1]. Terdapat beberapa jenis varietas pepaya yang paling populer dan banyak dijumpai di pasaran Indonesia yaitu pepaya California, pepaya Hawai, pepaya Bangkok, pepaya Red Lady, dan pepaya gunung. Pepaya California paling disukai karena memiliki keunggulan berupa ukuran buah yang beratnya berkisar antara $0,8-2 \mathrm{~kg} /$ perbuah, berkulit tebal dan halus, berbentuk lonjong, daging buahnya yang kenyal, dan buah matangnya berwarna kuning [2].

Menurut Badan Pusat Statistik 2018 konsumsi buah pepaya califonia memiliki nilai produksi sebanyak 875,112 ton pada tahun 2017 dan mengalami peningkatan pada tahun 2018 mempunyai nilai produksi sebanyak 887,591 ton dan selalu mengalami peningkatan setiap tahunnya [3]. Food \& Agriculture Organization ( $F A O$ ) menyatakan bahwa Indonesia adalah produsen buah pepaya terbesar ke lima di dunia setelah Brazil, Nigeria, India, dan Mexico [4]. Dengan nilai ekspor yang tinggi sangat dibutuhkan penanganan untuk menentukan mutu pepaya dan terdapat permasalahan dalam proses 
penentuan mutu buah pepaya. Proses penentuan mutu buah pepaya masih dilakukan secara konvensional yaitu dengan menggunakan visual mata manusia yang memiliki keterbatasan. Dalam proses indentifikasi mutu pepaya tersebut memiliki beberapa kelemahan yaitu membutuhkan tenaga yang lebih dalam memilah buah pepaya, dan tingkat persepsi manusia yang berbeda dalam penentuan keputusan, serta dalam prosesnya manusia dapat mengalami kelelahan sehingga tidak dapat menjamin konsistensi penentuan mutu buah pepaya tersebut [5].

Penelitian identifikasi mutu pepaya telah dilakukan oleh [5]. Pada penelitian tersebut dilakukan identifikasi tingkat ketuaan dan kematangan pepaya menggunakan metode jaringan syaraf tiruan yang memberikan hasil $97,8 \%$. Pada penelitian lain dilakukan oleh [6] dan [7] yaitu untuk menentukan identifikasi mutu pepaya menggunakan fuzzy memberikan hasil $75 \%$. Jaringan syaraf tiruan dapat digunakan untuk mengenali pola. Jaringan syaraf tiruan digunakan pada penelitian [5] untuk menentukan tingkat ketuaan pepaya. Jaringan syaraf tiruan juga digunakan pada penelitian [8] untuk menentukan kematangan roasting biji kopi yang memberikan hasil sebesar $76,7 \%$. Pada penelitian [9] jaringan syaraf tiruan digunakan untuk menentukan potensi glaukoma dan diabetes retinopathy yang memberikan hasil $91 \%$. Selain itu pada penelitian yang menggunakan jaringan syaraf tiruan yaitu [10] yang digunakan untuk klasifikasi American Sign Language memberikan hasil 99\%. Jaringan syaraf tiruan juga digunakan untuk klasifikasi jenis kacangkacangan yang memberikan hasil $99 \%$.

Penelitian ini dilakukan untuk mengetahui performa dari penerapan metode jaringan syaraf tiruan untuk identifikasi mutu pepaya. Penelitian ini juga dapat menjadi perbandingan dengan metode yang sudah ada untuk identifikasi mutu pepaya. Penelitian ini dilakukan dengan menggunakan metode backpropagation yang dapat menghasilkan tingkat akurasi yang cukup baik untuk mengenali objek berdasarkan warna dan tekstur. Penelitian ini menggunakan metode backpropagation jaringan syaraf tiruan dengan ekstraksi citra fitur warna $\mathrm{R}$ dan $\mathrm{G}$, ukuran, dan cacat (defect) dengan menggunakan dataset yang diambil secara langsung dalam penelitian.

Terdapat penelitian [6] diperoleh hasil tingkat akurasi menggunakan defuzzyfikasi metode Centorid dan Bisector sebesar $75 \%$, sedangkan tingkat akurasi dengan menggunakan defuzzyfikasi metode Means of Maximum, Largest of Maximum, dan Smallest of Maximum sebesar 70\%. Pada penelitian [8] mengenai klasifikasi roasting biji kopi menggunakan jaringan syaraf tiruan mendapatkan hasil terbaik dengan tingkat akurasi hasil proses training sebesar $82,7 \%$ sedangkan akurasi proses testing sebesar $76,7 \%$. Pada penelitian [7] untuk penentuan kualitas buah pepaya California dengan desain model fuzzy-tsukamoto menghasilkan tingkat akurasi sebesar $75 \%$.

Penelitian [11] mengenai klasifikasi jenis kacangkacangan menggunakan jaringan syaraf tiruan memperoleh hasil terbaik yaitu 99,8\% untuk accuracy, 99,6\% untuk precision, 99,8\% untuk recall yang menggunakan 20 neuron pada hidden layer. Pada penelitian [9] untuk mengidentifikasi potensi glaukoma dan diabetes retinopati melalui citra fundus dengan menggunakan jaringan syaraf tiruan menghasilkan rata-rata untuk recall sebesar $86,6 \%$, precision sebesar $86,6 \%$, dan untuk accuracy sebesar 91,06\%. Pada penelitian [12] melakukan klasifikasi mutu pepaya berdasarkan ciri tekstur GLCM menggunakan jaringan syaraf tiruan menghasilkan tingkat akurasi terbaik yaitu $86,11 \%$.

\section{METODE PENELITIAN}

\section{A. Studi Literatur}

Pada tahapan ini dilakukan pencarian dan pembelajaran berupa jurnal, buku, dan hasil penelitian yang berkaitan dengan topik penelitian ini, yaitu menggunakan metode backpropagation dengan ekstraksi fitur red, green, defect, mayor axis, dan minor axis untuk klasifikasi citra yang dalam penelitian ini merupakan citra buah pepaya California, dengan menggunakan beberapa faktor berupa warna kulit, ukuran, dan cacat (defect) dari objek tersebut.

\section{B. Pengumpulan Data Uji dan Data Training}

Pada tahapan ini dilakukan pengumpulan data training berupa dataset buah pepaya california yang diambil secara langsung pada saat penelitian. Dataset yang digunakan berupa format JPG. Kamera yang digunakan dalam penelitian ini ialah kamera Iphone 7+ dengan resolusi kamera belakang 12MP, pengambilan foto dengan jarak $25 \mathrm{~cm}$ yang diukur dari permukaan kulit buah pepaya. Tingkat pencahayaan pada media kotak adalah 497 Lux dengan background pengambilan foto menggunakan kertas putih.

TABEL 1. JUMLAH CITRA BUAH PEPAYA

\begin{tabular}{|c|c|c|}
\hline No & Kategori Pepaya & Jumlah Citra yang difoto \\
\hline 1 & Bagus & 50 \\
\hline 2 & Sedang & 50 \\
\hline 3 & Jelek & 50 \\
\hline \multicolumn{2}{|r|}{ Jumlah } & 150 \\
\hline
\end{tabular}




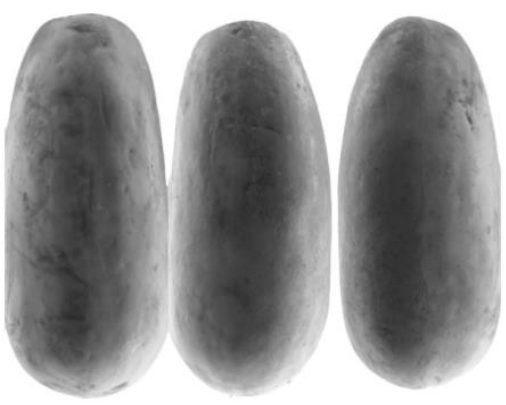

Gambar 1. Contoh Citra Pepaya

\section{Cropping Citra}

Setelah melakukan pengambilan data selanjutnya adalah cropping citra,dari citra asli di crop berdasarkan ukuran pepaya masing-masing.

\section{Perancangan Sistem}

Pada tahap ini, penulis akan melakukan sebuah perancangan sistem untuk penelitian mengenai mutu buah papaya.

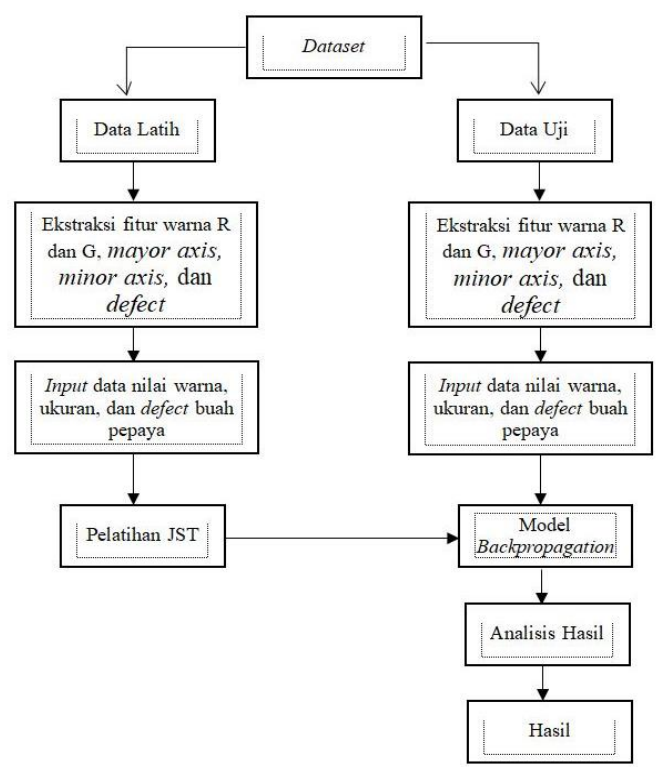

Gambar 2. Rancangan Klasifikasi Metode Backpropagation

1. Terdapat lima variabel input pada penelitian ini yaitu red, green, defect, mayor axis, dan minor axis yang akan digunakan dalam proses ekstraksi.

2. Untuk mencari nilai warna red dan green dapat dilakukan dengan cara membaca data atau citra pepaya yang dibuat melalui fungsi imread, lalu mencari nilai rata-rata dari red dan green.

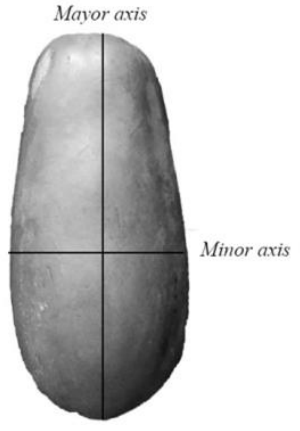

Gambar 3. Mayor Axis dan Minor Axis Citra Pepaya

3. Untuk mencari ukuran pepaya, menggunakan mayor axis dan minor axis sehingga mendapat ukuran dalam satuan piksel. Mayor axis sebagai panjang buah dan minor axis sebagai lebar buah.

4. Untuk mencari nilai defect, maka citra pepaya akan diekstraksi fitur dari RGB ke HSV, grayscale, dan black and white (hitam dan putih). Maka, didapatlah besar nilai hitam dan putih, yang mana warna putih merupakan bagian yang cacat atau busuk dan hitam merupakan bagian yang bagus. Berdasarkan nilai tersebut, maka dapat dihitung persentase kecacatan (defect) pada citra buah pepaya dengan rumus sebagai berikut:

Defect $(\%)=\frac{\text { Nilai white }}{\text { Nilai black }+ \text { nilai white })} * 100$

5. Kemudian nilai yang didapatkan dari ruang warna $\mathrm{R}$ dan $\mathrm{G}$, nilai piksel, dan nilai defect akan digunakan pada pelatihan jaringan syaraf tiruan backpropagation. Dataset akan dibagi menjadi data latih dan data uji dengan menggunakan cross validation yang akan di training menggunakan arsitektur multi layer network dengan 17 training function yang terdiri dari satu lapisan hidden layer dan dengan menggunakan neuron 10, 20, dan 25 .

\section{E. Implementasi dan Training Data}

Pada tahap ini dilakukan implementasi dari penelitian dan sistem yang telah dirancang sebelumnya. Data training diekstraksi fiturnya untuk mendapatkan fitur warna red dan green, fitur defect dan fitur ukuran berupa mayor axis dan minor axis. Fitur-fitur ini kemudian dijadikan input untuk jaringan syaraf tiruan. Jaringan syaraf tiruan dilatih menggunakan fitur-fitur ini untuk mengenali mutu pepaya tersebut. Setelah jaringan syaraf tiruan dilatih, langkah selanjutnya jaringan syaraf tiruan digunakan untuk menentukan mutu pepaya menggunakan data testing. 


\section{F. Uji Coba}

Pada tahap ini dilakukan pengujian dari sistem dalam melakukan klasifikasi mutu buah pepaya California dan hasil pengujian tersebut akurat atau tidak sesuainya dengan pendapat pakar mengenai kategori mutu pepaya bagus, sedang, dan jelek. Hasil akan dicatat untuk dilakukan analisa setelah semua pengujian selesai. Untuk menghitung tingkat akurasi dengan menggunakan Confusion Matrix.

TABEL 2. CONFUSION MATRIX

\begin{tabular}{|c|c|c|}
\hline \multirow{2}{*}{$\begin{array}{c}\text { Aktual } \\
\text { (Hasil Pakar) }\end{array}$} & $\begin{array}{c}\text { Classified As (Hasil } \\
\text { Sistem) }\end{array}$ & $\begin{array}{c}\text { Aktual } \\
\text { (Hasil Pakar) }\end{array}$ \\
\cline { 2 - 3 } & + & - \\
\hline+ & True Positives (A) & + \\
\hline- & False Positives (C) & - \\
\hline
\end{tabular}

Perhitungan akurasi dengan tabel confusion matrix adalah sebagai berikut :

$$
\text { Akurasi }=\frac{(\mathrm{A}+\mathrm{D})}{(\mathrm{A}+\mathrm{B}+\mathrm{C}+\mathrm{D})}
$$

Akurasi dapat didefinisikan sebagai tingkat kedekatan antara nilai prediksi dengan nilai aktual.

Presisi didefinisikan sebagai tingkat ketepatan antara informasi yang diminta oleh pengguna dengan jawaban yang diberikan oleh sistem. Rumus presisi adalah :

$$
\text { Presisi }=\frac{A}{(C+A)}
$$

Recall didefinisikan sebagai tingkat keberhasilan sistem dengan menemukan kembali sebuah informasi. Recall dihitung dengan rumus :

$$
\text { Recall }=\frac{\mathrm{A}}{(\mathrm{A}+\mathrm{D})}
$$

Presisi dan Recall dapat diberi nilai dalam bentuk angka dengan menggunakan perhitungan persentase $(1-100 \%)$ atau dengan menggunakan bilangan antara $0-1$. Sistem rekomendasi akan dianggap baik jika nilai presisi dan recallnya tinggi.

\section{HASIL DAN PEMBAHASAN}

Pada proses ini mengimplementasikan proses metodologi pada penelitian untuk mendapatkan hasil yang dibutuhkan dalam penelitian seperti, ekstraksi ciri dan model jaringan syaraf tiruan backpropagation.

\section{A. Implementasi Hasil Ekstraksi Ciri}

Hasil identifikasi buah papaya menggunakan model jaringan syaraf tiruan backpropagation dengan 17 training function. Dataset yang digunakan berupa 12 citra training dan 30 citra testing. Tahapan pertama adalah melakukan ekstraksi fitur berupa ekstraksi red, green, defect, mayor axis, dan minor axis yang disimpan dengan nama "hasil_kates". Berikut

\begin{tabular}{|c|c|c|c|c|c|c|c|}
\hline \multicolumn{7}{|c|}{$\boxplus 5 \times 150$ double } & \\
\hline & 1 & 2 & 3 & 4 & 5 & 6 & 7 \\
\hline 1 & 139.1203 & 164.1073 & 153.1783 & 143.4603 & 164.1727 & 150.6413 & 143.6511 \\
\hline 2 & 145.6318 & 168.5767 & 160.2293 & 146.9411 & 149.3365 & 143.6411 & 147.3518 \\
\hline 3 & 20.2796 & 29.4155 & 39.6849 & 16.8766 & 25.0638 & 23.4351 & 20.6925 \\
\hline 4 & $2.5665 e+03$ & $2.8975 e+03$ & $2.5423 e+03$ & $2.9205 e+03$ & $3.3433 \mathrm{e}+03$ & $2.8091 \mathrm{e}+03$ & $2.6504 \mathrm{e}+03$ \\
\hline 5 & $1.2191 e+03$ & $1.3651 e+03$ & 1.2898e+03 & $1.3681 e+03$ & $1.4222 \mathrm{e}+03$ & $1.1676 e+03$ & $1.2121 e+03$ \\
\hline 6 & & & & & & & \\
\hline
\end{tabular}
hasil ekstraksi fitur yang sudah dilakukan dapat dilihat pada Gambar 4.

Gambar 4. Hasil Ekstraksi Fitur

\section{B. Implementasi Model Jaringan Syaraf Tiruan Backpropagation}

Proses implementasi model jaringan syaraf tiruan dilakukan dengan menggunakan train tool pada MATLAB 2019a terhadap hasil ekstraksi ciri sehingga mampu untuk mengenali data latih. Kemudian untuk nilai target pada data latih disimpan dengan nama "dbtarget".

TABEL 3. NiLAI TARGET DATA LATIH

\begin{tabular}{|c|c|c|}
\hline Pepaya Bagus & Pepaya Sedang & Pepaya Jelek \\
\hline 1 & 0 & 0 \\
\hline 0 & 1 & 0 \\
\hline 0 & 0 & 1 \\
\hline
\end{tabular}

Kemudian tahap berikutnya adalah dengan melakukan cross validation untuk membentuk kelompok data yang ditentukan secara acak yang akan digunakan sebagai data latih dan data uji. Pada tahap ini menggunakan $k$-fold sebanyak 5, sehingga akan menghasilkan 5 kelompok data yang masingmasing terdiri dari 120 data latih dan 30 data uji.

\section{Pengujian Arsitektur Jaringan Syaraf Tiruan}

Dalam pengujian arsitektur jaringan syaraf tiruan menggunakan arsitektur multi layer network dimana model jaringan syaraf tiruan terdiri dari satu lapisan hidden layer. Dengan menggunakan data inputan sebanyak 4 neuron yang digunakan single hidden layer dan akan menghasilkan 3 output. Function training yang digunakan sebanyak 17 dan jumlah neuron yang dicoba adalah 10, 20, dan 25 sehingga terdapat 3 arsitektur jaringan syaraf tiruan yang berbeda. 
TABEL 4. PENENTUAN HIDDEN LAYER PADA TRAINING FUNCTION

\begin{tabular}{|c|c|c|}
\hline No & $\begin{array}{c}\text { Nama Training } \\
\text { Function }\end{array}$ & $\begin{array}{c}\text { Jumlah neuron pada } \\
\text { hidden layer }\end{array}$ \\
\hline 1 & trainbr & 10,20, dan 25 \\
\hline 2 & trainlm & 10,20, dan 25 \\
\hline 3 & trainbfg & 10,20, dan 25 \\
\hline 4 & traincgb & 10,20, dan 25 \\
\hline 5 & traincgf & 10,20, dan 25 \\
\hline 6 & traincgp & 10,20, dan 25 \\
\hline 7 & traingd & 10,20, dan 25 \\
\hline 8 & traingda & 10,20, dan 25 \\
\hline 9 & traingdm & 10,20, dan 25 \\
\hline 10 & traingdx & 10,20, dan 25 \\
\hline 11 & trainoss & 10,20, dan 25 \\
\hline 12 & trainrp & 10,20, dan 25 \\
\hline 13 & trainscg & 10,20, dan 25 \\
\hline 14 & trainb & 10,20, dan 25 \\
\hline 15 & trainc & 10,20, dan 25 \\
\hline 16 & trainr & 10,20, dan 25 \\
\hline 17 & trains & 10,20, dan 25 \\
\hline
\end{tabular}

D. Hasil Pengujian Jaringan Syaraf Tiruan Menggunakan Training Function

Pengujian jaringan syaraf tiruan menggunakan 17 training function menggunakan hasil dari implementasi jaringan syaraf tiruan yang dilakukan terhadap data latih menggunakan 1 hidden layer dengan jumlah neuron yang digunakan adalah 10 neuron, 20 neuron, dan 25 neuron.

Pada Tabel 5 dapat dilihat perbandingan hasil pengujian menggunakan 17 training function. Pada Tabel 5 dapat diketahui hasil terbaik untuk accuracy yaitu pada training function trainrp dengan menggunakan 20 neuron yaitu sebesar $82,67 \%$ dengan precision $75,24 \%$ dan recall $74 \%$. Hasil terendah yaitu pada training function trains dengan accuracy 71,11\% menggunakan neuron 10 dan 25 .

Secara keseluruhan, jaringan saraf tiruan dengan 20 neuron merupakan hasil yang terbaik dibandingkan dengan 10 neuron dan 25 neuron yaitu sebesar 77,76\%. Gambar 5, Gambar 6 dan Gambar 7 merupakan grafik perbandingan performa 17 training function. Gambar 5 merupakan merupakan perbandingan hasil training function menggunakan 10 neuron. Gambar 6 merupakan merupakan perbandingan hasil training function menggunakan 20 neuron. Gambar 7 merupakan merupakan perbandingan hasil training function menggunakan 25 neuron.

TABEL 5. HASIL 17 TRAINING FUNCTION

\begin{tabular}{|c|c|c|c|c|c|c|c|c|c|c|}
\hline \multirow[b]{2}{*}{ No } & \multirow{2}{*}{$\begin{array}{l}\text { Training } \\
\text { function }\end{array}$} & \multicolumn{3}{|c|}{10 Neuron } & \multicolumn{3}{|c|}{20 Neuron } & \multicolumn{3}{|c|}{25 Neuron } \\
\hline & & $\begin{array}{c}\text { Accuracy } \\
(\%)\end{array}$ & $\begin{array}{c}\text { Precision } \\
(\%)\end{array}$ & $\begin{array}{c}\text { Recall } \\
(\%)\end{array}$ & $\begin{array}{c}\text { Accuracy } \\
(\%)\end{array}$ & $\begin{array}{c}\text { Precision } \\
(\%)\end{array}$ & $\begin{array}{c}\text { Recall } \\
(\%)\end{array}$ & $\begin{array}{c}\text { Accuracy } \\
(\%)\end{array}$ & $\begin{array}{c}\text { Precision } \\
(\%)\end{array}$ & $\begin{array}{c}\text { Recall } \\
(\%)\end{array}$ \\
\hline 1 & trainbr & 76,15 & 65,28 & 64 & 76.8 & 66,12 & 65,33 & 72,44 & 60,61 & 58,67 \\
\hline 2 & trainlm & 76,67 & 63,71 & 62 & 77,78 & 70,32 & 66,67 & 76,64 & 62,52 & 62 \\
\hline 3 & trainbfg & 76,89 & 67,04 & 65,33 & 76,89 & 66,80 & 65,33 & 74,67 & 64 & 62 \\
\hline 4 & traincgb & 75,56 & 65,50 & 63,33 & 81,33 & 74,15 & 72 & 78,22 & 68,27 & 67,33 \\
\hline 5 & traincgf & 79,60 & 70,42 & 69,33 & 79,60 & 69,80 & 69,33 & 79,11 & 69,60 & 68,70 \\
\hline 6 & traincgp & 78,70 & 69,60 & 68 & 80,90 & 74,94 & 71,33 & 80 & 72 & 70 \\
\hline 7 & traingd & 73,50 & 63 & 60 & 73,33 & 62 & 60 & 75,40 & 65 & 63 \\
\hline 8 & traingda & 80 & 73.53 & 70 & 80,44 & 72,10 & 70,67 & 79,11 & 70,68 & 68,67 \\
\hline 9 & traingdm & 72 & 59 & 58 & 71,56 & 58,12 & 57,33 & 72,89 & 63,41 & 59,33 \\
\hline 10 & traingdx & 78.22 & 68,49 & 67,33 & 79,56 & 72,07 & 69,33 & 78,67 & 69,78 & 68,8 \\
\hline 11 & trainoss & 80,44 & 73,12 & 70,67 & 80,89 & 74,53 & 71,33 & 79,56 & 70,72 & 69,33 \\
\hline 12 & trainrp & 81,33 & 73,37 & 72 & 82,67 & 75,24 & 74 & 80,89 & 74,42 & 71,33 \\
\hline 13 & trainscg & 78,22 & 69,23 & 67,33 & 78,67 & 69 & 68 & 77,33 & 65,50 & 66 \\
\hline 14 & trainb & 71,11 & 58,72 & 56,67 & 72,44 & 61 & 58,67 & 71,11 & 57,74 & 56,67 \\
\hline 15 & trainc & $74,22 \%$ & $63,31 \%$ & $61.33 \%$ & $75,56 \%$ & $64,55 \%$ & $63,33 \%$ & $75,56 \%$ & $63,84 \%$ & $63,33 \%$ \\
\hline 16 & trainr & $75,11 \%$ & $66,33 \%$ & $62,67 \%$ & $78,22 \%$ & $70,35 \%$ & $67,33 \%$ & $74,67 \%$ & $63,96 \%$ & $62 \%$ \\
\hline 17 & trains & $73,78 \%$ & $62,45 \%$ & $60,67 \%$ & $75,11 \%$ & $62,25 \%$ & $62,67 \%$ & $74,67 \%$ & $63,46 \%$ & $62 \%$ \\
\hline \multicolumn{2}{|c|}{ Rata-rata } & $76,44 \%$ & $66,59 \%$ & $64,63 \%$ & $77,76 \%$ & $68,44 \%$ & $66,63 \%$ & $76,53 \%$ & $66,27 \%$ & $64,61 \%$ \\
\hline
\end{tabular}




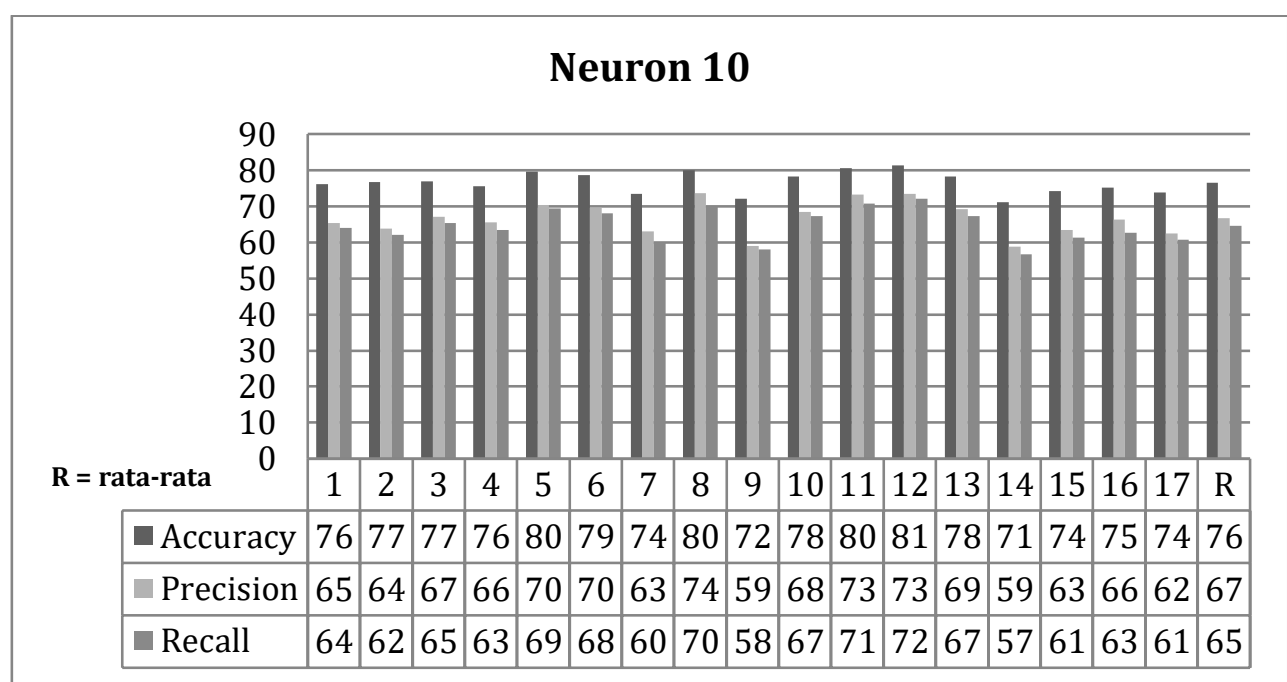

Gambar 5. Grafik Hasil 17 Training Function pada 10 Neuron

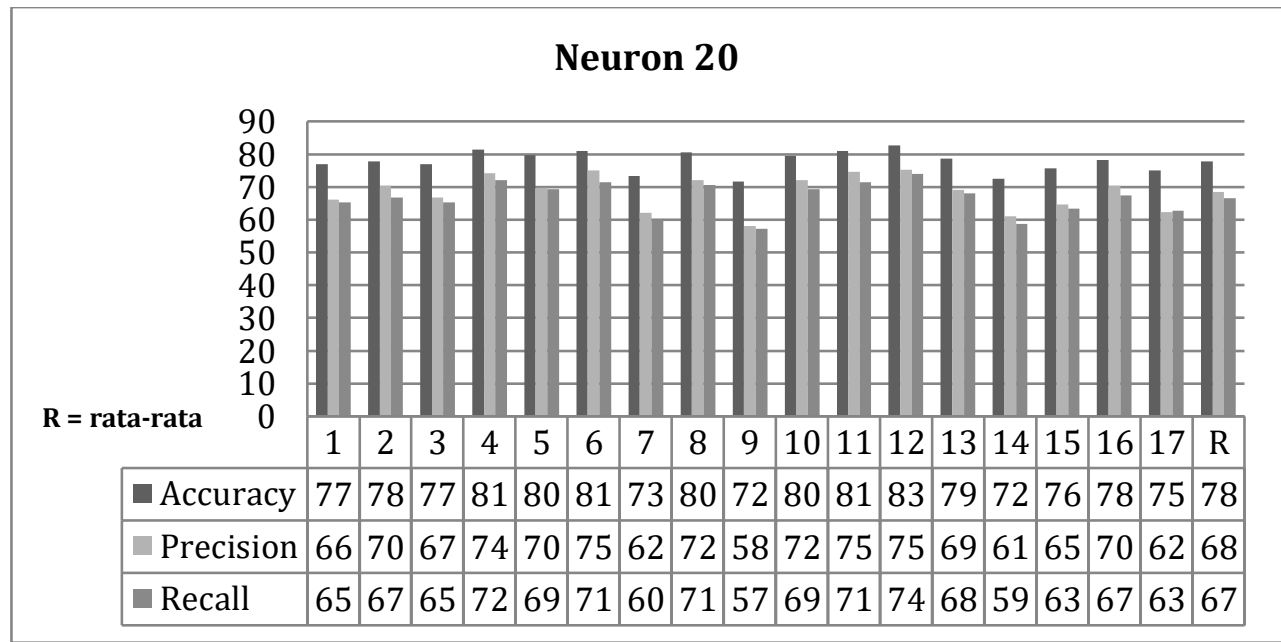

Gambar 6. Grafik Hasil 17 Training Function pada 20 Neuron

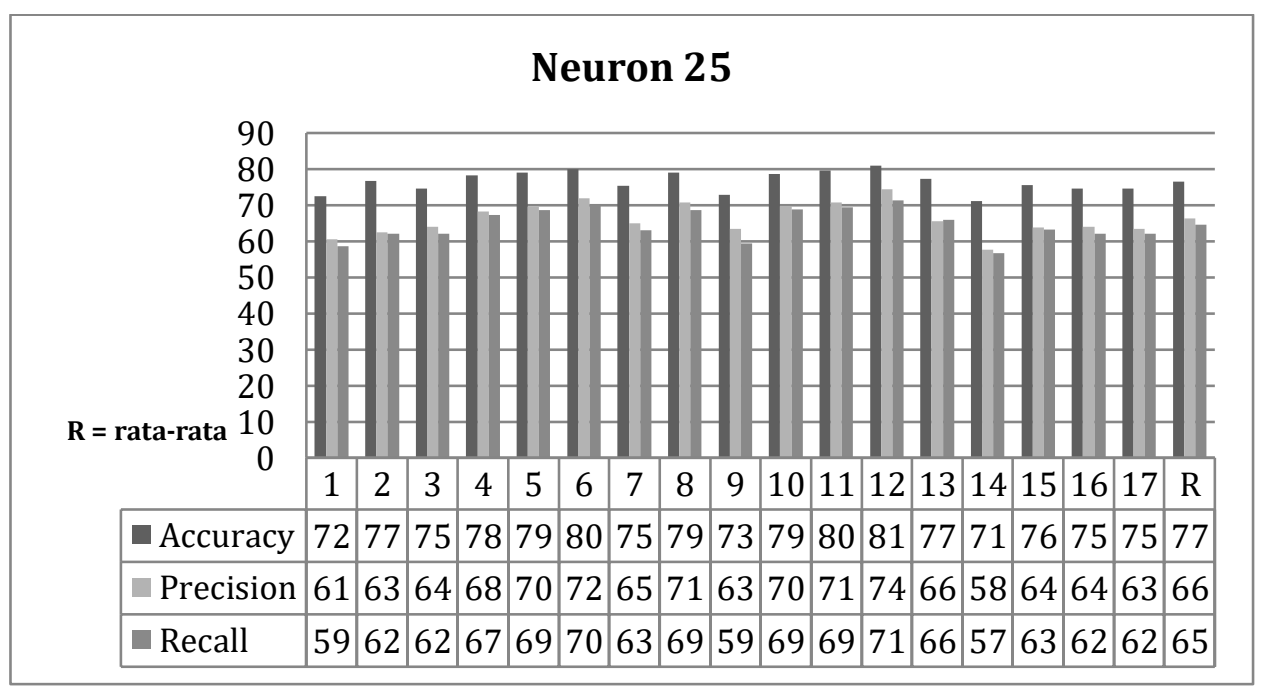

Gambar 7. Grafik Hasil 17 Training Function pada 25 Neuron

p-ISSN 2301-7988, e-ISSN 2581-0588

DOI : 10.32736/sisfokom.v10i1.1105, Copyright @2020

Submitted : February 11, 2021; Revised : April 4, 2021; Accepted : April 19, 2021; Published : April 20, 2021 


\section{KESIMPULAN}

Dari penelitian ini dapat disimpulkan bahwa arsitektur jaringan syaraf tiruan backpropagation yang memberikan hasil rata-rata terbaik yaitu dengan menggunakan 20 neuron hidden layer dengan hasil terbaik yaitu accurary $77,76 \%$, precision 68,44\%, dan recall 66,63\%. Dengan menggunakan 17 training function didapatkan hasil tertinggi pada trainrp dengan accurary $82,67 \%$, precision $75,24 \%$, dan recall $74 \%$ pada neuron 20 .

\section{REFERENCES}

[1] S. Ashari, Hortikultura aspek budidaya. Jakarta: UI-Press, 1995.

[2] I. Y, "Budidaya Pepaya California," 2011.

[3] Badan Pusat Statistik, "Statistik Tanaman Sayuran dan Buah-Buahan Semusim Indonesia 2018," Subdirektorat Stat. Hortik., p. 101, 2018.

[4] F. E. and S. D. Department, "Medium-term prospects for agricultural commodities (tropical fruits)," 2010.

[5] E. Syaefulloh and H. Purwadaria, "IDENTIFIKASI TINGKAT KETUAAN DAN KEMATANGAN PEPAYA (Carica papaya L.) IPB 1 DENGAN PENGOLAHAN CITRA DIGITAL DAN JARINGAN SYARAF TIRUAN," Agritech J. Fak. Teknol. Pertan. $U G M$, vol. 27, no. 2, pp. 75-81, 2007, doi: 10.22146/agritech.9496.

[6] M. E. Al Rivan and J. Suherman, "Penentuan Mutu Buah Pepaya
California (Carica Papaya L.) Menggunakan Fuzzy Mamdani," ELKHA, vol. 12, no. 2, p. 76, Oct. 2020, doi: 10.26418/elkha.v12i2.41164.

[7] M. E. Al Rivan, A. Octavia, and I. Wijaya, "DESAIN MODEL FUZZY-TSUKAMOTO UNTUK PENENTUAN KUALITAS BUAH PEPAYA CALIFORNIA (CARICA PAPAYA L.) BERDASARKAN BENTUK FISIK," Saintekom, vol. 11, no. 1, pp. 11-21, 2021.

[8] D. A. Nugraha and A. S. Wiguna, "Klasifikasi Tingkat Roasting Biji Kopi Menggunakan Jaringan Syaraf Tiruan Backpropagation Berbasis Citra Digital,” SMARTICS J., vol. 4, no. 1, pp. 1-4, 2018, doi: $10.21067 /$ smartics.v4i1.2165.

[9] M. E. Al Rivan and T. Juangkara, "Identifikasi Potensi Glaukoma dan Diabetes Retinopati Melalui Citra Fundus Menggunakan Jaringan Syaraf Tiruan," JATISI (Jurnal Tek. Inform. dan Sist. Informasi), vol. 6, no. 1, pp. 43-48, Sep. 2019, doi: 10.35957/jatisi.v6i1.158.

[10] M. E. Al Rivan and M. T. Noviardy, "Klasifikasi American Sign Language Menggunakan Ekstraksi Fitur Histogram of Oriented Gradients dan Jaringan Syaraf Tiruan," vol. 6, pp. 442-451, 2020.

[11] M. E. Al Rivan, N. Rachmat, and M. R. Ayustin, "Klasifikasi Jenis Kacang-Kacangan Berdasarkan Tekstur Menggunakan Jaringan Syaraf Tiruan,” J. Komput. Terap., vol. 6, no. 1, pp. 89-98, 2020, doi: doi.org/10.35143/jkt.v6i1.3546.

[12] F. Wibowo and A. Harjoko, "Klasifikasi Mutu Pepaya Berdasarkan Ciri Tekstur GLCM Menggunakan Jaringan Saraf Tiruan," Khazanah Inform. J. Ilmu Komput. dan Inform., vol. 3, no. 2, p. 100, 2018, doi: 10.23917/khif.v3i2.4516. 